\title{
Seedling Growth and Recovery in Response to Waterlogging of Wheat Cultivars Grown in the Yangtze River Basin of China from Three Different Decades
}

\author{
Jinfeng Ding ${ }^{1}$, Shengnan $\mathrm{Su}^{1}$, Yuxue Zhang ${ }^{1}$, Chunyan $\mathrm{Li}^{1}$, Xinkai Zhu ${ }^{1} \&$ Wenshan Guo ${ }^{1,2}$ \\ 1 Jiangsu Key Laboratory of Crop Genetics and Physiology/Co-Innovation Center for Modern Production \\ Technology of Grain Crops/Wheat Research Institute, Yangzhou University, Yangzhou, China \\ ${ }^{2}$ Joint International Laboratroy of Agriculture and Agri-Product Safety/Joint Laboratory in Agricultural Sciences \\ between AAFC and Yangzhou University, Yangzhou University, Yangzhou, China \\ Correspondence: Jinfeng Ding, Wheat Research Institute, Yangzhou University, Yangzhou, China. Tel: \\ 0086-0514-8797-2131. E-mail: jfdin@yzu.edu.cn
}

Received: January 16, 2017

Accepted: February 21, 2017

Online Published: March 15, 2017

doi:10.5539/jas.v9n4p128

URL: https://doi.org/10.5539/jas.v9n4p128

\begin{abstract}
Waterlogging is a major constraint on wheat (Triticum aestivum L.) production, especially in the Yangtze River Basin of China (YR). A container experiment was designed to investigate wheat-seedling growth and short-term recoveryin response to waterlogging. Cultivars commonly grown in theYR from three different decades, namely, Yangmai 1 (1970s), Yangmai 158 (1990s), and Yangfumai 4 (2010s), were selected. Seedling waterlogging significantly postponed leaf development, as well as decreased the number of tillers and adventitious roots per plant, seedling height, leaf area, specific leaf dry weight, shoot dry weight, root dry weight, and root/shoot ratio. After a 20-day recovery phase, the leaf stage, seedling height, and root/shoot ratio recovered to the control level, whereas the adverse effects of waterlogging on the number of tillers per plant, leaf area, and shoot dry weight intensified. Significant differences were found in seedling growth among the three wheat cultivars. Yangfumai 4 showed the highest number of adventitious rootsper plant and the highest specific leaf dry weightbut the lowest seedling height, leaf area, and dry weights of shoots and roots. However, Yangfumai 4 showed the lowest percentage decrease in all growth parameters after both waterlogging and recovery. These results suggested thatimprovement inadventitious root numberper plant and specific leaf dry weight may be indicators ofresistance to waterlogging in wheat.
\end{abstract}

Keywords: wheat, different-decade cultivars, the Yangtze River basin of China, waterlogging, seedling growth

\section{Introduction}

Waterlogging is amajor constraint on wheat yield and production worldwide and affects approximately 10-15 million hectares (ha) of wheat globally, representing 15\%-20\% ofcultivated area annually (Setter \& Waters, 2003). More than $12 \%$ of the wheat planting area in Chinais located in the Yangtze River Basin (YR) (Cheng et al., 2012). In this area, precipitation normally exceeds the water requirement of wheat, and is irregularly distributed on spatial and temporal scales. Moreover, a rice-wheat rotation system is generally conducted in the YR, resulting inwater-saturated soil because of frequent rainfalls and excessive irrigation during the rice-growing season (Wu et al., 2015). Because of the increase of extreme climate eventsin the recent years, the frequency of rainfall intensity has increased and this increases the frequency of waterlogging (Schumacher \& Johnson, 2006; Shao et al., 2013).

The effects of waterlogging on wheat growth are diverse and complex. Multiple plant traits are affected, including the phenology, morphology, anatomy, nutrition, metabolism (e.g. an aerobic catabolism and anoxia tolerance), postanoxic damage, and recovery (Setter \& Waters, 2003). At the agronomic level, typical responses to waterlogging include decreased plant height; inhibited antioxidant capacity of leaves and roots; relatively low levels of photosynthesis, respiration, and transpiration; and reduced growth of the roots and shoots; and reduced tillers, kernel number, and grain yield (Brisson et al., 2002; Jiang et al., 2006; Olgun et al., 2008; Hossain \& Uddin, 2011). In addition, the severity of waterlogging's unfavourable effectson wheat growth depends on several factors, such assoil and weather conditions (Setter \& Waters, 2003), cultivars grown (Dickin et al., 2009; 
Haque et al., 2012), cultivation technologies (Wu et al., 2013), growth stage of the plants (Shao et al., 2013; Wu et al., 2015), depth of water levels (Malik et al., 2001), and severity and duration of waterlogging (Collaku \& Harrison, 2002; Malik et al., 2002).

Thus far, most studies have investigated the effects on wheat growth responses during waterlogging, though the ability of wheat to recover after waterlogging has been considered to be equally important recently (Setter \& Waters, 2003; Malik et al., 2001). The evaluation of the recovery after waterlogging includes the abilityof the plants to rapidly recover (Setter \& Waters, 2003), growth conditions under a prolonged recovery period (Malik et al., 2001, 2002; Araki et al., 2012), and effects on final yield (Melhuishg et al., 1991; Musgrave, 1994; Dickin \& Wright, 2008). Therefore, the physiological mechanisms for waterlogging tolerance must not only consider the effects of waterlogging on wheat growth but also consider the ability of the wheat to recover from it.

In the YR, there has beenfive to six wheat cultivar renewals since the 1950s (Cheng et al., 2012), and the yield potential has achieved 9 tons per ha in field conditions (Ding et al., 2016). Grain yield improvements were mainly associated with single-spike yield increase, specifically improvement of the kernel number, and weight (Tian et al., 2011). While many studies that investigated the genetic gain in wheat cultivars were conducted in different wheat-growing regions under appropriate water conditions (Fischer et al., 1998), few studies focused on the responses and mechanisms of wheat cultivarsto waterlogging from different periods in the evolutionary process.

Previous investigations observed that the grain yield after seedling waterlogging much lesser than that of the late growth stages (Wu et al., 2015), because waterlogging inhibited the growth of early tilling and disrupted the suitable establishment of the large spikes (Malik et al., 2002; Dickin et al., 2009), and it affected the long-term growth and physiology of the wheat (Malik et al., 2002). However, other studies foundthat seedling waterlogging did not significantly affect the grain yield because of thelong-term recovery after waterlogging (Cannell et al., 1980; Dickin et al., 2009). The difference in the results above could be attributed to the different experimental environments or cultivar types. Therefore, the purpose of the present experiment conducted in the YR was to: (i) investigate the effects on seedling growth and short-term recovery after waterlogging, and (ii) determine whether the present cultivars have higher waterlogging tolerance compared withearly cultivars. The information provided in this study could contribute to the improvement of wheat production in the YR.

\section{Materials and Methods}

\subsection{Plant Materials and Growth Conditions}

Experiments were conducted at the Agricultural Experiment Station $\left(32^{\circ} 39^{\prime} \mathrm{E}, 119^{\circ} 42^{\prime} \mathrm{N}\right)$ of the Agricultural College of Yangzhou University, China. Three wheat (Triticum aestivum L.) cultivarscollected from different decades, the Yangmai 1 (1970s), Yangmai 158 (1990s), and Yangfumai 4 (2010s), that were widely extended and planted in the YR were used.

Container experiments were performed under natural conditions of radiation and temperature. The meteorological data during the experiment, including temperature, sunshine. And precipitation accumulation, are shown in Figure 1. Each of the plastic containers used were $26 \mathrm{~cm}$ wide at the top, $18 \mathrm{~cm}$ wide at the bottom, and $26 \mathrm{~cm}$ deep, and contained 8 drainage holes $(1 \mathrm{~cm}$ diameter) at the base. Before filling, fine soil for each container was prepared by sieving through a $5-\mathrm{mm}$ mesh and then mixed with the following fertilizers: $3.6 \mathrm{~g}$ inorganic compound fertilizer (containing $15 \% \mathrm{~N}, 15 \% \mathrm{P}_{2} \mathrm{O}_{5}$, and $15 \% \mathrm{~K}_{2} \mathrm{O}$ ) and $0.83 \mathrm{~g}$ urea (containing $46 \% \mathrm{~N}$ ) The soil was loamy clay and contained $9.62 \mathrm{~g} \mathrm{~kg}^{-1}$ organic matter, $79.95 \mathrm{mg} \mathrm{kg}^{-1}$ alkali hydrolysable $\mathrm{N}, 38.52 \mathrm{mg}$ $\mathrm{kg}^{-1}$ Olsen-P, and $85.37 \mathrm{mg} \mathrm{kg}^{-1}$ exchangeable $\mathrm{K}$. The soil was then watered to $5 \mathrm{~L}$ at the same rate of natural soil compaction $\left(1.40 \mathrm{~g} \mathrm{~cm}^{-3}\right)$. Each container was filled with $11 \mathrm{~kg}$ of soil. Aftertheseedlings weresowed in each container, an additional $1 \mathrm{~kg}$ of soil was used to cover them. The experiments were conducted without biotic stresses, and all the weeds were removed by hand.

\subsection{Experimental Design}

The experiments were based on a randomized split-plot design. The waterlogging and control treatments were primary plots, and the subplots were the three wheat cultivars from different decades. There were 6 treatments with 12 replicates. Thirteen seeds per pot were sown at a depth of 2-3 cm on November 3, 2014. Seedlings were then thinned to 10 plants per pot after germination (Zadoks growth stage GS11). Waterlogging treatments were applied for 10 days from November 20 (GS12) to November 30 (GS14). After waterlogging, seedling recovery conditions were observed for 20 days, and the seedling were then harvested on December 20 (GS15).

The pots were placed into larger containers $(98 \mathrm{~cm} \times 76 \mathrm{~cm} \times 67 \mathrm{~cm})$ with a $0-2 \mathrm{~cm}$ layer of water above the surface of each pot during the entire period of the waterlogging treatment as described be de San Celedonio et al. 
(2014). After the waterlogging treatment, the pots were retrieved from the containers and then placed in the field. The pots were allowed to drain freely before normal irrigation was reinstated. The control pots, from sowing to harvest, and the waterlogging pots before and after treatment were maintained at $80 \%$ of field capacity through irrigation (Bao, 2007). Volumetric soil water content of a 0-10 cm-layer of each pot was continuously monitored using a soil moisture-measuring instrument (TZS-1K, TOP Instrument, China). Irrigation was applied when necessary.
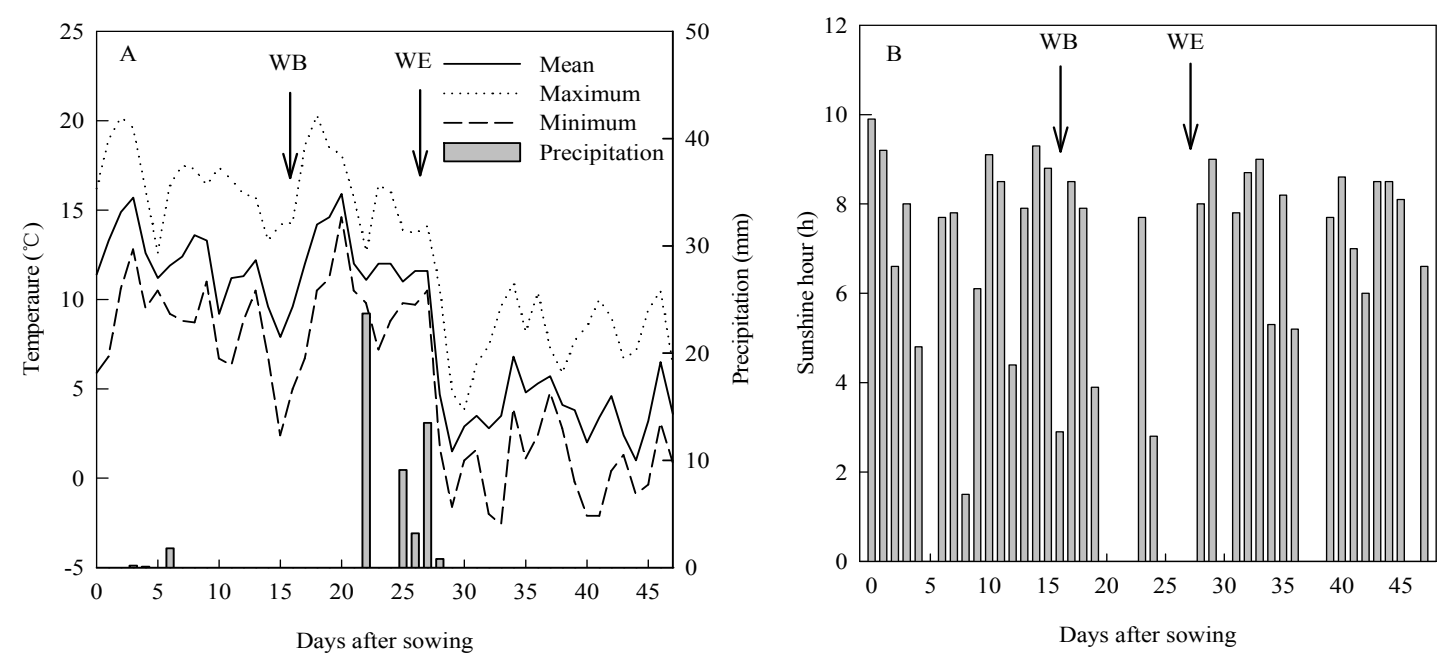

Figure 1. The daily mean, maximum, and minimum temperature and precipitation (A), and sunshine hours (B) during the experiment

Note. WB and WE denote waterlogging treatment beginning and ending, respectively.

\subsection{Sampling and Measurements}

The morphology and the growth conditions of the seedlings were measured four times after the waterlogging treatment and after a 20-day recovery phase. Ten whole plants per pot, including the shoots and roots, were harvested and washed to determine the number of tillers per plant, number of adventitious roots per plant, and seedling height. The leaf stage of the mainstem was calculatedaccording to Haun (1973), where,

Leaf stage $=$ Number of visible leaves on the mainstem $+($ Length of youngest visible leaf/Length of second Youngest visible leaf)

Plants were divided into shoots (the visible leaf blade and stem) and roots. The leaf area was measured using a portable area meter (LI-3000C, LI-COR Inc., USA).

The dry weight of each component was determined after drying at $70{ }^{\circ} \mathrm{C}$ to constant weight. Parameters for the morphology and growth condition of the seedlings were calculated as follows:

Specific leaf dry weight $\left(\mathrm{mg} \mathrm{cm}^{-2}\right)=$ Leaf dry weight $\left(\mathrm{mg}\right.$ plant $\left.{ }^{-1}\right) /$ Leaf area $\left(\mathrm{cm}^{2}\right.$ plant $\left.{ }^{-1}\right)$

Root $/$ shoot ratio $=$ Root dry weight $\left(\mathrm{mg} \mathrm{plant}^{-1}\right) /$ Shoot dry weight $\left(\mathrm{mg} \mathrm{plant}^{-1}\right)$

\subsection{Statistical Analysis}

Each variable was subjected to two-way analysis of variance (ANOVA) under a split-plot design using a statistical package (DPS 7.05). Treatment mean differences were separated by the least significant difference in a significant level of 0.05 test. To assess the difference among the cultivars of each treatment, the percentage change of the seedling growth traitsunder waterlogging condition in comparison with that of the control were calculated.

\section{Results}

\subsection{Leaf Stage}

As shown in Tables 1 and 2, the leaf stage of the waterlogged wheat was significantly lower than that of the non-waterlogged control plantby up to $5 \%$, but the former quickly recovered after 20 days. No significant 
differences among the cultivars were observed, and no interaction between the waterlogging treatments and the cultivars was apparent.

\subsection{Tillers and Adventitious Roots per Plant}

The number of tillers per plant of the waterlogged wheat was significantly reduced by approximately $6 \%$ after waterlogging and approximately $18 \%$ after recovery (Tables 1 and 2). Significant differences were found among the three cultivars from different decades. Cultivar Yangmai 1 had the highest number of tillers per plant after waterlogging, but it had the lowest number of tillers per plant after recovery, demonstrating that the tiller occurrence in Yangmai 1 was the slowest during the recovery phase. During the waterlogging treatment, Yangmai 1 showed the highest percentage decrease in the number of tillers per plant after both the waterlogging and the recovery relative to the other cultivars.

Waterlogging significantly decreased the number of adventitious roots per plant by approximately $15 \%$ after waterlogging and approximately $13 \%$ after recovery (Tables 1 and 2). Significant differences in the number of adventitious roots per plant were found among the cultivars. The number of adventitious roots per plant was highest in Yangfumai 4, and its percentage decrease in the same cultivar was lowest after both the waterlogging and the recovery.

Table 1. Analysis of variance forseedling growth traits after waterlogging and recovery

\begin{tabular}{|c|c|c|c|c|c|c|}
\hline \multirow{3}{*}{ Seedling growth traits } & \multicolumn{6}{|c|}{ Source of variation } \\
\hline & \multicolumn{3}{|c|}{ After waterlogging } & \multicolumn{3}{|c|}{ After recovery } \\
\hline & $\mathrm{T}$ & $\mathrm{C}$ & $\mathrm{T} \times \mathrm{C}$ & $\mathrm{T}$ & $\mathrm{C}$ & $\mathrm{T} \times \mathrm{C}$ \\
\hline Leaf stage & $67.69^{*}$ & $0.01 \mathrm{~ns}$ & $0.01 \mathrm{~ns}$ & $7.56 \mathrm{~ns}$ & $0.05 \mathrm{~ns}$ & $0.05 \mathrm{~ns}$ \\
\hline Number of tillers per plant & $16.30 *$ & $30.92 * *$ & $1.01 \mathrm{~ns}$ & $68.15^{*}$ & $88.45^{* *}$ & $17.77 * *$ \\
\hline Number of adventitious roots per plant & $51.56^{*}$ & $252.40 * *$ & $0.06 \mathrm{~ns}$ & $26.33^{*}$ & $136.36^{* *}$ & $0.04 \mathrm{~ns}$ \\
\hline Seedling height $(\mathrm{cm})$ & $20.61 *$ & $34.46^{* *}$ & $0.22 \mathrm{~ns}$ & $2.32 \mathrm{~ns}$ & $74.68^{* *}$ & $0.36 \mathrm{~ns}$ \\
\hline Leaf area $\left(\mathrm{cm}^{2}\right.$ plant $\left.{ }^{-1}\right)$ & $60.82 *$ & $31.32 * *$ & $0.79 \mathrm{~ns}$ & $124.71^{* *}$ & $7.29 *$ & $1.45 \mathrm{~ns}$ \\
\hline Specific leaf dry weight $\left(\mathrm{mg} \mathrm{cm}^{-2}\right)$ & $29.33^{*}$ & $2.79 \mathrm{~ns}$ & $1.39 \mathrm{~ns}$ & $41.43^{*}$ & $5.71 *$ & $1.12 \mathrm{~ns}$ \\
\hline Shoot dry weight (mg plant $\left.{ }^{-1}\right)$ & $2084.46^{* *}$ & $168.80^{* *}$ & $2.34 \mathrm{~ns}$ & $18.81^{*}$ & $73.24 * *$ & $10.10^{* *}$ \\
\hline Root dry weight (mg plant ${ }^{-1}$ ) & $180.06^{* *}$ & $591.06 * *$ & $63.21 * *$ & $921.73 * *$ & $60.58 * *$ & $14.44 * *$ \\
\hline Root/shoot ratio & $129.56^{* *}$ & $10.50^{* *}$ & $2.79 \mathrm{~ns}$ & $6.95 \mathrm{~ns}$ & $3.71 \mathrm{~ns}$ & $0.32 \mathrm{~ns}$ \\
\hline
\end{tabular}

Note. $\mathrm{T}=$ waterlogging treatments; $\mathrm{C}=$ cultivars; $*=$ Significant difference at $P \leq 0.05 ; * *=$ Significant difference at $P \leq 0.01 ; \mathrm{ns}=$ significant difference. The number indicates $F$ value.

Table 2. Effect of waterlogging treatments on the leaf stage, number of tillers per plant, and number of adventitious roots per plant of different cultivars

\begin{tabular}{|c|c|c|c|c|c|c|c|}
\hline \multirow[t]{2}{*}{ Treatments } & \multirow[t]{2}{*}{ Cultivars } & \multicolumn{2}{|c|}{ Leaf stage } & \multicolumn{2}{|c|}{$\begin{array}{c}\text { Number of tillers } \\
\text { per plant }\end{array}$} & \multicolumn{2}{|c|}{$\begin{array}{c}\text { Number of adventitious } \\
\text { roots per plant }\end{array}$} \\
\hline & & AW & $\mathrm{AR}$ & AW & $\mathrm{AR}$ & AW & $\mathrm{AR}$ \\
\hline \multirow[t]{3}{*}{ Control } & Yangmai 1 & 4.00 & 5.20 & 1.80 & 2.80 & 1.27 & 3.10 \\
\hline & Yangmai 158 & 4.00 & 5.20 & 1.50 & 3.00 & 1.64 & 3.92 \\
\hline & Yangfumai 4 & 4.00 & 5.20 & 1.50 & 2.93 & 2.02 & 4.22 \\
\hline \multirow[t]{3}{*}{ Waterlogging } & Yangmai 1 & 3.83 & 5.10 & 1.70 & 2.30 & 1.08 & 2.73 \\
\hline & Yangmai 158 & 3.80 & 5.15 & 1.47 & 2.62 & 1.42 & 3.51 \\
\hline & Yangfumai 4 & 3.80 & 5.16 & 1.49 & 2.71 & 1.84 & 3.91 \\
\hline L.S.D. $(p=0.05)$ & & 0.53 & 0.79 & 0.19 & 0.15 & 0.29 & 0.58 \\
\hline
\end{tabular}

Note. $\mathrm{AW}=$ measurement after waterlogging; $\mathrm{AR}=$ measurement after recovery; L.S.D. $=$ least significant difference.

\subsection{Seedling Height}

The seedling height of the waterlogged wheat was significantly lower than that of the non-waterlogged wheat by approximately $6 \%$, but no significant difference between their seedling heights was observedafter recovery 
(Tables 1 and 3). Significant differences were present among cultivars. Yangfumai 4 had the shortest seedling height and the lowest percentage decrease in seedling height. No significant interactions between the treatments and the cultivars were apparent.

\subsection{Leaf Area and Specific Leaf Dry Weight}

The leaf area of the waterlogged wheat was significantly lower than that of the control plants by approximately $10 \%$ after waterlogging and approximately $11 \%$ after recovery. Specific leaf dry weight of the waterlogged wheat was significantly lower than that of the control plants by approximately $8 \%$ after waterlogging and approximately $11 \%$ after recovery (Tables 1 and 3). Significant differences among the three cultivars were observed with regard to leaf area and specific leaf dry weight after treatment and leaf area after recovery except specific leaf dry weight after waterlogging. Yangfumai 4 showed the lowest leaf area and the greatest specific leaf dry weight among the cultivars. Furthermore, Yangfumai 4 had the lowest percentage decrease in leaf area and specific leaf dry weight both after waterlogging and after recovery. No significant interactions between the treatments and the cultivars in terms of leaf area and specific leaf dry weight were observed.

Table 3. Effect of waterlogging treatments on seedling height, leaf area, and specific leaf dry weight of different cultivars

\begin{tabular}{|c|c|c|c|c|c|c|c|}
\hline \multirow{2}{*}{ Treatments } & \multirow{2}{*}{ Cultivars } & \multicolumn{2}{|c|}{ Seedling height $(\mathrm{cm})$} & \multicolumn{2}{|c|}{ Leaf area $\left(\mathrm{cm}^{2}\right.$ plant $\left.^{-1}\right)$} & \multicolumn{2}{|c|}{ Specific leaf dry weight $\left(\mathrm{mg} \mathrm{cm}^{-2}\right)$} \\
\hline & & $\mathrm{AW}$ & $\mathrm{AR}$ & AW & $\mathrm{AR}$ & AW & AR \\
\hline \multirow[t]{3}{*}{ Control } & Yangmai 1 & 18.62 & 19.21 & 18.83 & 26.28 & 2.56 & 2.08 \\
\hline & Yangmai 158 & 18.01 & 18.92 & 15.78 & 26.09 & 2.67 & 2.15 \\
\hline & Yangfumai 4 & 15.34 & 16.24 & 14.01 & 24.13 & 2.72 & 2.22 \\
\hline \multirow[t]{3}{*}{ Waterlogging } & Yangmai 1 & 17.70 & 18.53 & 17.30 & 23.64 & 2.35 & 1.90 \\
\hline & Yangmai 158 & 16.88 & 18.05 & 14.14 & 23.23 & 2.52 & 2.02 \\
\hline & Yangfumai 4 & 14.75 & 15.75 & 13.64 & 22.57 & 2.74 & 2.09 \\
\hline \multicolumn{2}{|c|}{ L.S.D. $(p=0.05)$} & 2.04 & 2.06 & 2.60 & 3.12 & 0.22 & 0.27 \\
\hline
\end{tabular}

Note. $\mathrm{AW}=$ measurement after waterlogging; $\mathrm{AR}=$ measurement after recovery; L.S.D. $=$ least significant difference.

\subsection{Shoot and Root Dry Matter and Root/Shoot Ratio}

The shoot dry weight, root dry weight, and root/shoot ratio of the waterlogged wheat was lower by approximately $10 \%, 32 \%$, and $24 \%$, respectively, than those of the non-waterlogged wheat after waterlogging, and approximately $19 \%, 25 \%$, and $9 \%$, respectively, after recovery (Table 4). Significant differences were observed among the different treatments and cultivars, except for the root/shoot ratio after recovery (Table 1). Among the cultivars, Yangfumai 4 showed the lowest shoot and root dry weight after waterlogging, though significant differences was not observed between the root dry weight of Yangmai 158 and that of Yangfumai 4 under waterlogging. After recovery, however, Yangmai 1 had the lowest shoot and root dry weight, and significant differences were not observed between Yangmai 158 and Yangfumai 4. The lowest root/shoot ratio was observed in Yangmai 158 after waterlogging, and in Yangfumai 4 after recovery. Yangfumai 4 also demonstrated the lowest percentage decrease in root dry weight and root/shoot ratio both after waterlogging and after recovery.

\section{Discussion}

Previous studies reported that after seedling waterlogging, the number of adventitious roots and tillers formed per plant decreased, and the length, surface area, and nitrogen concentration of leaves, as well as the root and shoot dry weight and root/shoot ratio, were reduced (Malik et al., 2002; Robertson et al., 2009; Haque, 2012; Shao et al., 2013; Tiryakıoğlu et al., 2015). The present study showed that seedling waterlogging from GS12 to GS14 significantly disrupted the leaf stage growth and decreased the number of tillers per plant, number of adventitious roots per plant, seedling height, leaf area, specific leaf dry weight, shoot dry weight, root dry weight, and root/shoot ratio (Tables 1, 2, 3, and 4). Our results were similar to those of the previous studied although we used different environments, cultivars, and waterlogging methods. As indicated in Table 4, the decrease percentage in the dry weight was higher in the roots compared to that in the shoots. This finding implies that waterlogging has a much considerable effect on root development versus shoot development. In a previous study, 
the decrease in the relative growth rate of the roots was observed to be higher than that of the shoots during waterlogging (Malik et al., 2001).

Table 4. Effect of waterlogging treatments on shoot dry weight, root dry weight, and root/shoot ratio of different cultivars

\begin{tabular}{|c|c|c|c|c|c|c|c|}
\hline \multirow{2}{*}{ Treatments } & \multirow{2}{*}{ Cultivars } & \multicolumn{2}{|c|}{ Shoot dry weight (mg plant ${ }^{-1}$ ) } & \multicolumn{2}{|c|}{ Root dry weight (mg plant ${ }^{-1}$ ) } & \multicolumn{2}{|c|}{ Root/shoot ratio } \\
\hline & & AW & AR & AW & $\mathrm{AR}$ & AW & $\mathrm{AR}$ \\
\hline \multirow[t]{3}{*}{ Control } & Yangmai 1 & 83.33 & 221.48 & 68.51 & 121.23 & 0.82 & 0.55 \\
\hline & Yangmai 158 & 64.41 & 248.26 & 45.43 & 134.71 & 0.70 & 0.54 \\
\hline & Yangfumai 4 & 55.07 & 240.64 & 39.07 & 123.75 & 0.71 & 0.51 \\
\hline \multirow[t]{3}{*}{ Waterlogging } & Yangmai 1 & 74.68 & 180.61 & 46.33 & 90.39 & 0.62 & 0.50 \\
\hline & Yangmai 158 & 60.53 & 228.30 & 32.87 & 113.30 & 0.54 & 0.50 \\
\hline & Yangfumai 4 & 52.20 & 229.54 & 31.92 & 111.02 & 0.61 & 0.48 \\
\hline \multicolumn{2}{|c|}{ L.S.D. $(p=0.05)$} & 5.52 & 17.74 & 5.56 & 11.62 & 0.06 & 0.04 \\
\hline
\end{tabular}

Note. $\mathrm{AW}=$ measurement after waterlogging; $\mathrm{AR}=$ measurement after recovery; L.S.D. $=$ least significant difference.

After a 20-day recovery phase, no significant reduction in the leaf stage, seedling height, and root/shoot ratio between the two treatments (Table 1). However, the number of tillers and adventitious roots per plant, leaf area, specific leaf dry weight, and shoot and root dry weight were significantly reduced (Tables 1, 2, 3, and 4). Robertson et al. (2009) observed that waterlogging considerably inhibited the growth of the primary tillers anddelayed the productionof new tillers, thoughit did not affect the nitrogen concentration of the youngest expanded leaf after recovery. Shao et al. (2013) found that photosynthetic rate and transpiration rapidly returned to control levels after the soil was drained. However, Malik et al. (2001) demonstrated that the growth rates of the shoots and roots in intensified waterlogged treatments only partially recovered after a 14-day recovery period. In 2002, Malik et al. then found that the shoot mass remained significantly lower because of the waterlogging treatments after a 25-day recovery period. These results clearly demonstrated that seedling growth can not recover to control levels after a short-term recovery period, though some physiological trails can recover. Our results were consistent with their experimental results. In addition, whether grain yield is substantially reduced because of seedling waterlogging remains controversial (Dickin et al., 2009; Wu et al., 2015). Further research is thus necessary to determine the effects of seedling waterlogging on wheat yield in the YR.

The researchers from the previous studies focused on the effects of genetic improvements on grain yield and the correlated characteristics of wheat (Fischer et al., 1998; Tian et al., 2011). They rarely investigated differences among the seedling growths. This study showed significant differences among the seedling growths of the three wheat cultivars grown in different decades (Table 1). The modern cultivar Yangmai 4 showed the highest number of adventitious roots per plant and the largest specific leaf dry weight, but it had the lowest seedling height, leaf area, and shoot and root dry weight (Tables 2, 3, and 4). Notably, Yangmai 4 had the lowest percentage decrease in all these parameters both after waterlogging and after recovery, demonstrating that it had the highest waterlogging resistance. Huang et al. (1997) reported that the effects of hypoxia on shoot and root growth were more substantial in waterlogging-sensitive cultivars because they had a relatively slow recovery. However, D. K. Singh and V. Singh (2003) reported that the degree of waterlogging tolerance, which was expressed as the percentage growth rate under waterlogged conditions relative to the non-waterlogged control conditions, can not actually reflect the waterlogging resistance of different cultivars. Thus, the evaluation of the waterlogging resistance of the additional cultivars grown in the YR requires other methods.

Ourresults suggest that improvement in the number of adventitious roots per plant and specific leaf dry weight may be correlated with increased waterlogging resistance. Hayashi et al. (2013) showed that root length density is related to the maintenance of water uptake, photosynthesis, and yield production in common wheat grown under waterlogged conditions. Chakraborty et al. (2008) considered that relatively high specific leaf dry weight indicates healthy biomass, and can further promote photosynthesis. Furthermore, multiple waterlogging resistance traits have been proposed, such as high carbohydrate status, aerenchyma formation in roots, and suitable root system architecture (Huang \& Johnson, 1995; Dickin \& Wright, 2008; Haque et al., 2012; Hayashi et al., 2013). Further research is thus necessary to investigate the waterlogging response of wheat cultivars at other growth stages. 


\section{Acknowledgements}

This work was supported by the grants from the National Natural Science Foundation of China (31401317), the National Key Research and Development Program of China (2016YFD0300405), the Special Scientific Research Fund of the Ministry of Agriculture (201503130), the Priority Academic Program Development of Jiangsu Higher Education Institutions, the University Scientific and Technological Innovation Team of Jiangsu Province, and Science and Technology Innovation Group and Outstanding Talents Support Program of Yangzhou University.

\section{References}

Araki, H., Hossain, M. A., \& Takahashi, T. (2012). Waterlogging and hypoxia have permanent effects onwheat root growth and respiration. Journal of Agronomy and Crop Science, 198, 264-275. https://doi.org/10.1111/ j.1439-037X.2012.00510.x

Bao, S. D. (2007). Soil and agricultural chemistry analysis. Beijing: China Agricultural Press.

Brisson, N., Rebiere, B., Zimmer, D., \& Renault, P. (2002). Response of the root system of a winter wheat crop to waterlogging. Plant and Soil, 243, 43-55. https://doi.org/10.1023/A:1019947903041

Cannell, R. Q., Belford, R. K., Gales, K., Dennis, C. W., \& Prew, R. D. (1980). Effects of waterlogging at different stages of development on the growth and yield of winter wheat. Journalof the Science of Food and Agriculture, 31, 117-132. https://doi.org/10.1002/jsfa.2740310203

Chakraborty, D., Nagarajan, S., Aggarwal, P., Gupta, V. K., Tomar, P. K., Garg, R. N., \& Kalra, N. (2008). Effect of mulching on soil and plant water status, and the growth and yield of wheat (Triticum aestivum L.) in a semi-arid environment. Agricultural Water Management, 95, 1323-1334. https://doi.org/10.1016/j.agwat. 2008.06.001

Cheng, S., Guo, W., \& Wang, L. (2012). Wheat in South China. Nanjing, China: Jiangsu Science and Technology Press.

Collaku, A., \& Harrison, S. A. (2002). Losses in wheat due to waterlogging. Crop Science, 42, 444-450. https://doi.org/10.2135/cropsci2002.0444

Dickin, E., \& Wright, D. (2008). The effects of winter waterlogging and summer drought on the growth and yield of winter wheat (Triticum aestivum L.). European Journal of Agronomy, 28, 234-244. https://doi.org/10.1016/j.eja.2007.07.010

Dickin, E., Bennett, S., \& Wright, D. (2009). Growth and yield responses of UK wheat cultivars to winter waterlogging. The Journalof Agriculture Science, 147, 127-140. https://doi.org/10.1017/S002185960 8008289

Ding, J., Zi, Y., Li, C., Peng, Y., Zhu, X., \& Guo, W. (2016). Dry matter accumulation, partitioning, and remobilization in high-yielding wheat under rice-wheat rotation in China. Agronomy Journal, 108, 604-614. https://doi.org/10.2134/agronj2015.0114

Fischer, R. A., Rees, D., Sayre, K. D., Lu, Z. M., Condon, A. G., \& Saavedra, A. L. (1998). Wheat yield progress associated with higher stomatal conductance and photosynthetic rate, and cooler canopies. Crop Science, 38, 1467-1475. https://doi.org/10.2135/cropsci1998.0011183X003800060011x

Haque, E., Oyanagi, A., \& Kawaguchi, K. (2012). Aerenchyma formation in the seminal roots of Japanese wheat cultivars in relation to growth under waterlogged conditions.Plant Production Science, 15, 164-173. https://doi.org/10.1626/pps.15.164

Haun, J. R. (1973). Visual quantification of wheat development. Agronomy Journal, 65, $116-119$. https://doi.org/10.2134/agronj1973.00021962006500010035x

Hossain, M. A., \& Uddin, S. N. (2011). Mechanisms of waterlogging tolerance in wheat: Morphological and metabolic adaptations under hypoxia or anoxia. Australian Journal of Crop Science, 5, 1094-1101.

Huang, B., \& Johnson, J. W. (1995). Root respiration and carbohydrate status of two wheat genotypes in response to hypoxia. Annals of Botany, 75, 427-432. https://doi.org/10.1006/anbo.1995.1041

Jiang, Y., \& Wang, K. (2006). Growth, physiological, and anatomical responses of creeping bentgrass cultivars to different depths of waterlogging. Crop Science, 46, 2420-2426. https://doi.org/10.2135/cropsci2005.11.0402

Liu, R., Yang, C., Zhang, G., Zhang, L., Yang, F., \& Guo, W. (2015). Root recovery development and activity of cotton plants after waterlogging. Agronomy Journal, 107, 2038-2046. https://doi.org/10.2134/agronj14.0567 
Malik, A. I., Colmer, T. D., Lambers, H., \& Schortemeyer, M. (2001). Changes in physiological and morphological traits of roots and shoots of wheat in response to different depths of waterlogging. Australian Journal of Plant Physiology, 28, 1121-1131. https://doi.org/10.1071/PP01089

Malik, A. I., Colmer, T. D., Lambers, H., Setter, T. L., \& Schortemeyer, M. (2002). Short-term waterlogging has long-term effects on the growth and physiology of wheat. New Phytologist, 153, 225-236. https://doi.org/10.1046/j.0028-646X.2001.00318.x

Melhuish, F. M., Humphreys, E., Muirhead, W. A., \& White, R. J. G. (1991). Flood irrigation of wheat on a transitional red-brown earth. I. Effect of duration of ponding on soil water, plant growth, yield and $\mathrm{N}$ uptake. Australian Journal of Agricultural Research, 42, 1023-1035. https://doi.org/10.1071/AR9911023

Musgrave, M. E. (1994). Waterlogging effects on yield and photosynthesis in eight winter wheat cultivars. Crop Science, 34, 1314-1318. https://doi.org/10.2135/cropsci1994.0011183X003400050032x

Olgun, M., MetinKumlay, A., CemalAdiguzel, M., \& Caglar, A. (2008). The effect of waterlogging in wheat (T. aestivum L.). Acta Agriculturae Scandinavica, Section B-Soil \& Plant Science, 58, 193-198. https://doi.org/10.1080/09064710701794024

Robertson, D., Zhang, H., Palta, J. A., Colmer, T., \& Turner, N. C. (2009). Waterlogging affects the growth, development of tillers, and yield of wheat through a severe, but transient, $\mathrm{N}$ deficiency. Crop and Pasture Science, 60, 578-586. https://doi.org/10.1071/CP08440

Romina, P., Abeledo, L. G., \& Miralles, D. J. (2014). Identifying the critical period for waterlogging on yield and its components in wheat and barley. Plant and Soil, 378, 265-277. https://doi.org/10.1007/ s11104-014-2028-6

Schumacher, R. S., \& Johnson, R. H. (2006). Characteristics of US extreme rain events during 1999-2003. Weather and Forecasting, 21, 69-85. https://dx.doi.org/10.1175/WAF900.1

Setter, T. L., \& Waters, I. (2003). Review of prospects for germplasm improvement for waterlogging tolerance in wheat, barley and oats. Plant and Soil, 253, 1-34. https://oi.org/10.1023/A:1024573305997

Shao, G., Lan, J., Yu, S., Liu, N., Guo, R., \& She, D. (2013). Photosynthesis and growth of winter wheat in response to waterlogging at different growth stages. Photosynthetica, 51, 429-437. https://doi.org/10.1007/ s11099-013-0039-9

Singh, D. K., \& Singh, V. (2003). Seed size and adventitious (nodal) roots as factors influencing the tolerance of wheat to waterlogging. Australian Journal of Agricultural Research, 54, 969-977. https://doi.org/10.1071/ AR02174

Tian, Z., Jing, Q., Dai, T., Jiang, D., \& Cao, W. (2011). Effects of genetic improvements on grain yield and agronomic traits of winter wheat in the Yangtze River Basin of China. Field Crop Research, 124, 417-425. https://doi.org/10.1016/j.fcr.2011.07.012

Tiryakıŏlu, M., Karanlik, S., \& Arslan, M. (2015). Response of bread-wheat seedlings to waterlogging stress. Turkish Journal of Agriculture and Forestry, 39, 807-816. https://doi.org/10.3906/tar-1407-124

Wu, J. D., Li, J. C., Wei, F. Z., Wang, C. Y., Zhang, Y., \& Sun, G. (2014). Effects of nitrogen spraying on the post-anthesis stage of winter wheat under waterlogging stress. Acta Physiologiae Plantarum, 36, 207-216. https://doi.org/10.1007/s11738-013-1401-z

Wu, X., Tang, Y., Li, C., Wu, C., \& Huang, G. (2015). Chlorophyll fluorescence and yield responses of winter wheat to waterlogging at different growth stages. Plant Production Science, 18, 284-294. https://doi.org/10.1626/pps.18.284

\section{Copyrights}

Copyright for this article is retained by the author(s), with first publication rights granted to the journal.

This is an open-access article distributed under the terms and conditions of the Creative Commons Attribution license (http://creativecommons.org/licenses/by/4.0/). 